Part of Journal of Research of the National Bureau of Standards, Volume 26, January 1941

\title{
THERMAL EXPANSION OF ELECTROLYTIC CHROMIUM
}

By Peter Hidnert

\section{ABSTRACT}

The linear thermal expansion of two samples of electrolytic chromium was investigated at various temperatures between $-105^{\circ}$ and $+715^{\circ}$ C. During the first heating or heatings, when hydrogen presumably was being evolved, the samples contracted in an irregular manner. After a few heatings, however, the irregularities disappeared and smooth expansion curves were obtained. It appears also, that the linear thermal expansion of electrolytic chromium, when it is first heated, may be affected by variables such as the temperature, time and rate of heating, previous treatment, etc. The following equations were derived for the length, $L_{t}$, at any temperature, $t$, between $-100^{\circ}$ and $+700^{\circ} \mathrm{C}$, and for the coefficient of expansion, $a_{t}$, at any temperature, $t$, between $-75^{\circ}$ and $+650^{\circ} \mathrm{C}$ :

and

$$
L_{t}=L_{0}\left[1+\left(5.88 t+0.00774 t^{2}-0.00000388 t^{3}\right) 10^{-6}\right]
$$

$$
a_{t}=\left(5.88+0.01548 t-0.00001163 t^{2}\right) 10^{-6} \text {. }
$$

The density of the sample of electrolytic chromium containing 99.3 percent of chromium increased 2.4 percent and the volume decreased 2.3 percent, after three cycles of heating to $500^{\circ} \mathrm{C}$ and cooling to room temperature. The length decreased 1.1 percent.

\section{CONTENTS}

Page

I. Introduction

II. Materials investigated.

III. Apparatus .

IV. Results

V. Discussion

VI. Summary and conclusions

VII. References._.

\section{INTRODUCTION}

The main objects of the use of chromium electroplating are the prolongation of the life of metal or alloy parts subject to wear or temperature and the production of a decorative effect. The porosity of new deposits of electroplated chromium coatings has been observed to increase for several weeks or on heating [1], ${ }^{1}$ and the development of cracks in chromium plating during atmospheric exposure at ordinary temperatures has been discussed by several observers [2, 3]. Determinations of the linear thermal expansion of electrolytic chromium therefore appeared to be desirable for a possible explanation of the behavior of chromium platings, particularly when heated.

Disch [4] appears to be the first investigator who published data on the linear thermal expansion of chromium. He obtained the sample of chromium from Firma Th. Goldschmidt A.-G. in Essen,

\footnotetext{
1 The numbers in brackets indicate the references at the end of this paper.
} 
Germany, but he did not report any information about its chemical composition, preparation, or treatment. In 1922 Chevenard [5] published a curve indicating the coefficients of linear thermal expansion of chromium containing 98.3 percent of chromium. He also failed to give information about its preparation or treatment.

In 1931 Hidnert [6] presented to the American Physical Society data on the linear thermal expansion of a sample of electrolytic chromium containing 99.3 percent of chromium. The present paper includes additional data on the thermal expansion of this sample and on another sample of electrolytic chromium.

\section{MATERIALS INVESTIGATED}

Table 1 gives the chemical composition and the density of the two samples of electrolytic chromium investigated. Sample $1359 \mathrm{~A}$ was prepared at the National Bureau of Standards by G. E. Renfro, and sample 1328I was prepared by Union Carbide \& Carbon Research Laboratories, Inc., New York, N. Y.

It was reported in 1931 [6] that chromium produced at the National Bureau of Standards, under conditions similar to those for sample $1359 \mathrm{~A}$, was found to contain about 0.1 percent of hydrogen.

The data in table 1 fail to account for the remaining 0.6 percent in sample $1359 \mathrm{~A}$ or the 1.2 percent in sample 1328I. Extensive investigation would be required to decide whether these undetermined portions consisted of (a) hydrogen in greater amount than was found by analysis of similar specimens, or (b) oxygen in some form, such as $\mathrm{Cr}_{2} \mathrm{O}_{3}$ or $\mathrm{Cr}(\mathrm{OH})_{3}$.

TABLE 1.-Chemical composition and density of electrolytic chromium

\begin{tabular}{|c|c|c|c|c|c|c|c|c|}
\hline \multirow{2}{*}{ Sample } & \multirow{2}{*}{ Material } & \multicolumn{6}{|c|}{ Chemical composition s } & \multirow{2}{*}{$\begin{array}{l}\text { Den- } \\
\text { sity b }\end{array}$} \\
\hline & & $\mathrm{Cr}$ & $\mathrm{Fe}$ & $\mathrm{Si}$ & $\mathrm{Mn}$ & $\mathrm{Pb}$ & $\mathrm{Cu}$ & \\
\hline $\begin{array}{l}1359 \mathrm{~A} . . . \\
1328 \mathrm{I} . . .\end{array}$ & $\left\{\begin{array}{l}\text { Tube, length } 300 \mathrm{~mm} \text {, outside diameter } 9 \mathrm{~mm} \text {, } \\
\text { inside diameter } 8 \mathrm{~mm} \text {. } \\
\text { Three pieces, each } 8 \mathrm{~mm} \text { in length }\end{array}\right.$ & $\begin{array}{c}\% \\
99.3 \\
98.7\end{array}$ & $\begin{array}{c}\% \\
0.002 \\
.003\end{array}$ & $\begin{array}{c}\% \\
0.002 \\
(0,1)\end{array}$ & $\begin{array}{l}\% \\
(c) \\
(c)\end{array}$ & $\begin{array}{l}\% \\
(0) \\
(0)\end{array}$ & $\begin{array}{l}\% \\
(0) \\
(0)\end{array}$ & $\left\{\begin{array}{l}\mathrm{g} / \mathrm{cm}^{3} \\
6.934{ }^{\circ} \\
7.103 \cdot \\
7.03 \mathrm{~g}\end{array}\right.$ \\
\hline
\end{tabular}

a Determined by R. M. Fowler, formerly of the National Bureau of Standards.

b Determined by E. Hill and S. Alpher, formerly of $\mathrm{t}^{\mathrm{h}}$ National Bureau of Standards.

- Not detected.

d At $22.5^{\circ} \mathrm{C}$ before first expansion test (see fig. 1).

- At $22.3^{\circ} \mathrm{C}$ after third expansion test (see fig. 1).

$i$ Spectrographic analysis by C. C. Kiess, of the National Bureau of Standards, indicated traces of $\mathrm{Si}$ and $\mathrm{C}$.

At $25^{\circ} \mathrm{C}$ (on duplicate pieces before heating).

\section{APPARATUS}

Sample 1359 A was investigated at various temperatures between $-105^{\circ}$ and $+706^{\circ} \mathrm{C}$ with the precision-comparator type of thermalexpansion apparatus described by Souder and Hidnert [7]. Tests 1, $2,3,9$, and 10 were made with the white furnace shown at the left of figure 1 of their publication. Figure 4 of the same publication shows the details of mounting the sample in the furnace. Tests 4 to 8, inclusive, were made with the oil bath shown at the extreme right of figure 1 of the publication by Souder and Hidnert [7]. Figure 3 
of their publication shows the sample, sample holder, and contact fingers for the vertical position wires used in the oil bath.

On account of the small pieces of chromium available for sample 1328I, the interferometer method [8] of measuring thermal expansion was employed. Five tests were made with this method at various temperatures between $21^{\circ}$ and $715^{\circ} \mathrm{C}$. At each observation, the temperature was kept constant for a sufficiently long time to make certain that the sample had attained temperature equilibrium.

\section{RESULTS}

Ten tests were made on the linear thermal expansion of sample $1359 \mathrm{~A}$, and five tests were made on sample 1328I. Figure 1 shows the observations obtained in the first three tests on the linear thermal expansion of sample 1359A, and figure 2 shows the observations in the last two tests of this sample. Figure 3 shows the observations obtained in five tests on sample 1328I. Each expansion curve was plotted from a different origin. The dotted portions of some curves indicate that in these regions sufficient observations were not obtained to locate the curves definitely. In each test, the numbers adjoining the observations represent the time, in hours, from the time of the initial observation.

In tests 1 to 3 on sample 1359A (fig. 1 ), the sample was heated to $500^{\circ} \mathrm{C}$ and cooled to room temperature in the furnace in an atmosphere of air. During the first heating to $500^{\circ} \mathrm{C}$ the sample contracted considerably, probably with an evolution of hydrogen. ${ }^{2}$ At $500^{\circ} \mathrm{C}$, the sample was 0.7 percent shorter than the initial length before heating. On cooling the sample to room temperature, the observations appeared to lie on a smooth curve. After cooling the sample to room temperature it was 1.1 percent shorter than before heating.

The expansion curve obtained in the second heating of sample $1359 \mathrm{~A}$ is regular except in the neighborhood of $500^{\circ} \mathrm{C}$. This slight irregularity was perhaps also accompanied by evolution of hydrogen. The contraction curve obtained on cooling in the second test is regular and lies below the expansion curve.

The expansion curve obtained in the third heating of sample $1359 \mathrm{~A}$ is smooth. It may therefore be assumed that no appreciable amount of hydrogen was evolved during this heating. The observations on cooling during the third test lie slightly below the expansion curve.

The expansion and contraction curves of the second and third tests of sample $1359 \mathrm{~A}$ are nearly parallel to the contraction curve of the first test.

The fourth test on sample $1359 \mathrm{~A}$ between $-105^{\circ}$ and $+100^{\circ} \mathrm{C}$, and tests 5 to 8 , inclusive, between room temperature and $300^{\circ} \mathrm{C}$, were made in the oil bath. The sample was surrounded by pentane at temperatures between $-105^{\circ}$ and $+20^{\circ} \mathrm{C}$, and by Renown engine oil at temperatures between $20^{\circ}$ and $300^{\circ} \mathrm{C}$.

The observations of tests 9 and 10 on sample 1359A shown in figure 2 , were obtained in the furnace between room temperature and

2 A qualitative chemical test was made on duplicate pieces of sample 1328I, and it was found that hydrogen was evolved on heating. 


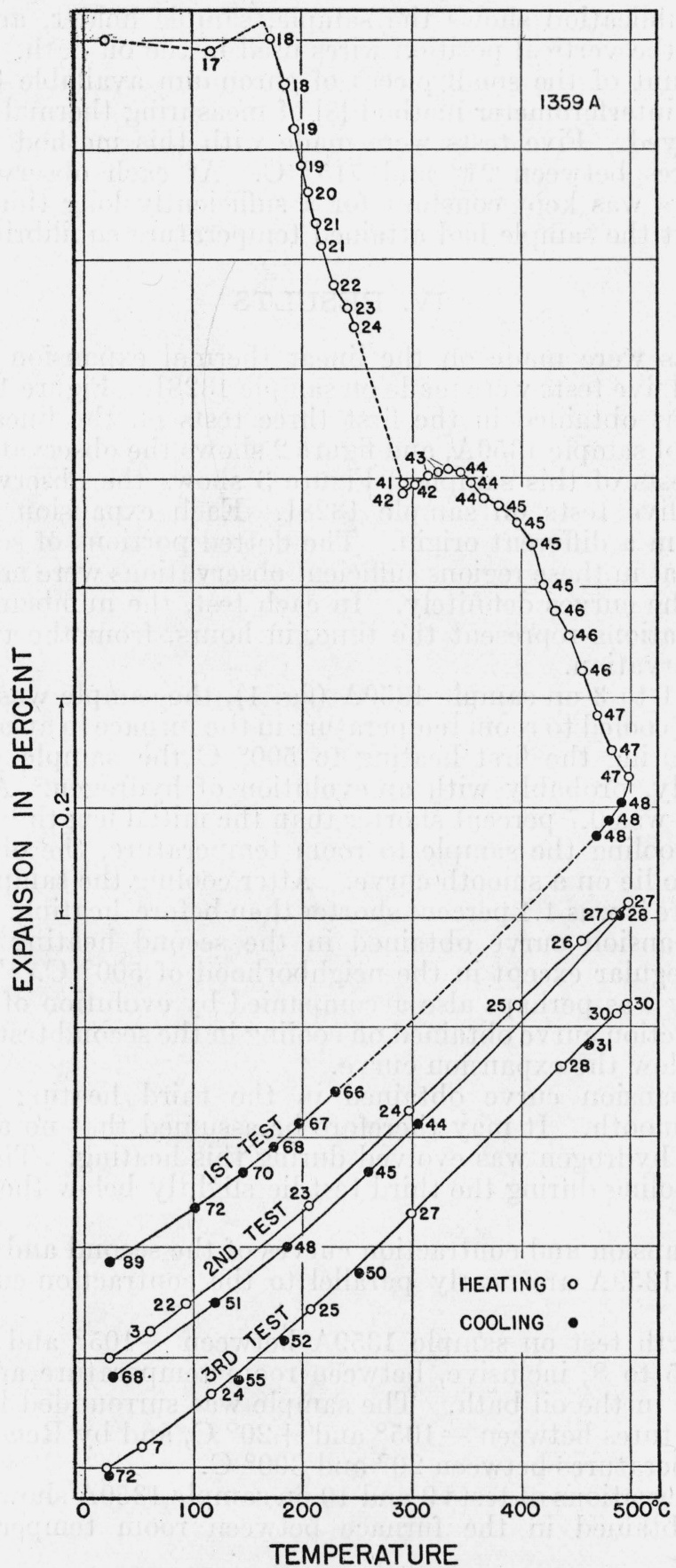

Figure 1.-Linear thermal expansion of electrolytic chromium, 99.3 percent (tests 1 to 3 , inclusive).

Each number adjoining an observation indicates the time, in hours, from the time of the initial observation. 
about $700^{\circ} \mathrm{C}$. In test 9 , the rate of expansion decreased above $500^{\circ}$ $\mathrm{C}$, probably with additional evolution of hydrogen. The contraction curve on cooling in test 9 is regular and lies below the expansion curve. The expansion curve in the tenth test is smooth, and the observations on cooling lie slightly below the expansion curve.

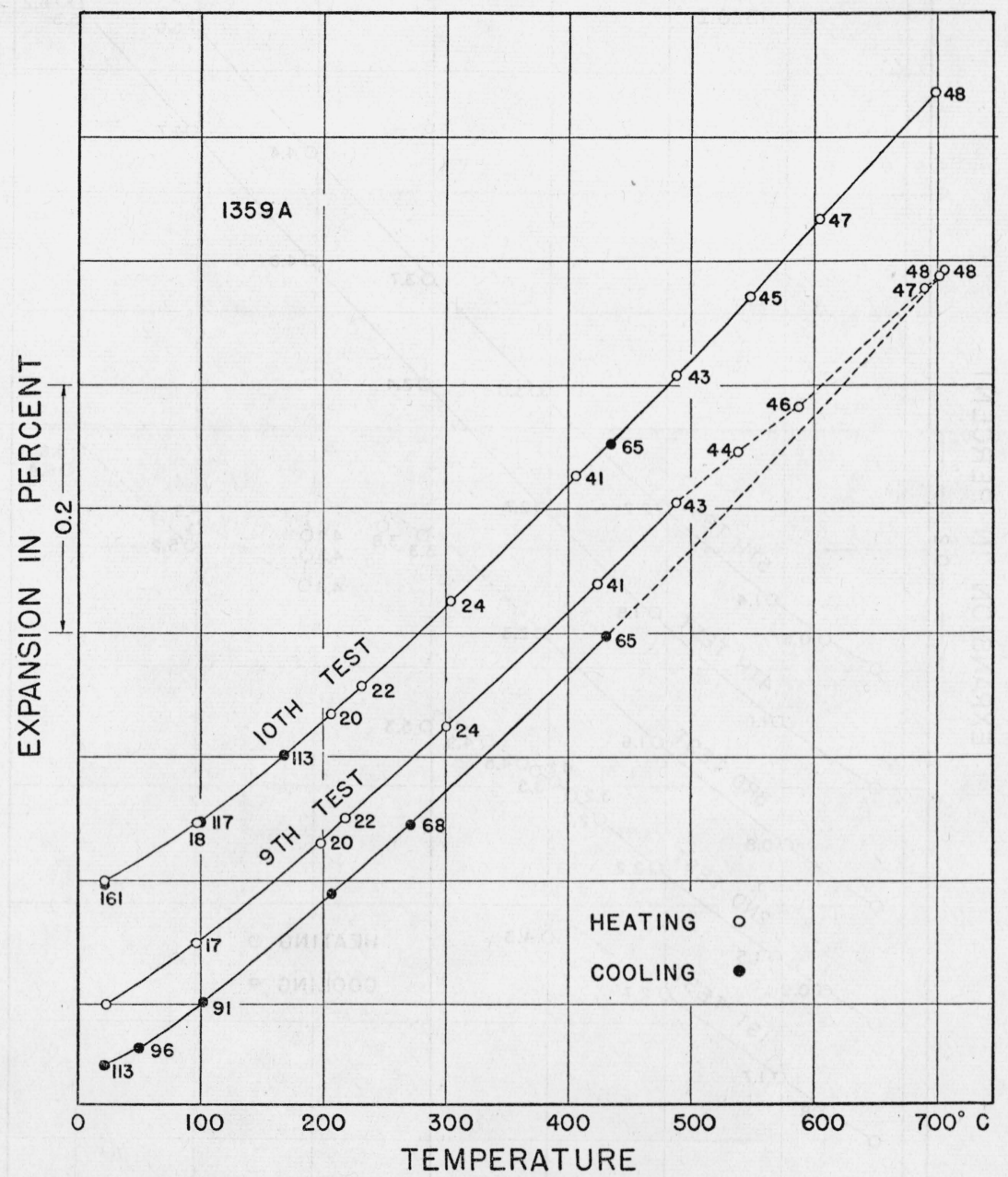

FIGURE 2.-Linear thermal expansion of electrolytic chromium, 99.3 percent (tests 9 and 10 )

Each number adjoining an observation indicates the time, in hours, from the time of the initial observation.

The observations obtained on sample 1328I in tests 1 to 5 are shown in figure 3. In these tests by the interferometer method, the three pieces of chromium representing the sample were heated in a furnace in an atmosphere of air. During the first heating, the sample contracted in the neighborhood of $300^{\circ} \mathrm{C}$. In the second heating, the rate of expansion decreased between $200^{\circ}$ and $400^{\circ} \mathrm{C}$., and the sample contracted in the neighborhood of $400^{\circ} \mathrm{C}$. The sample was heated 


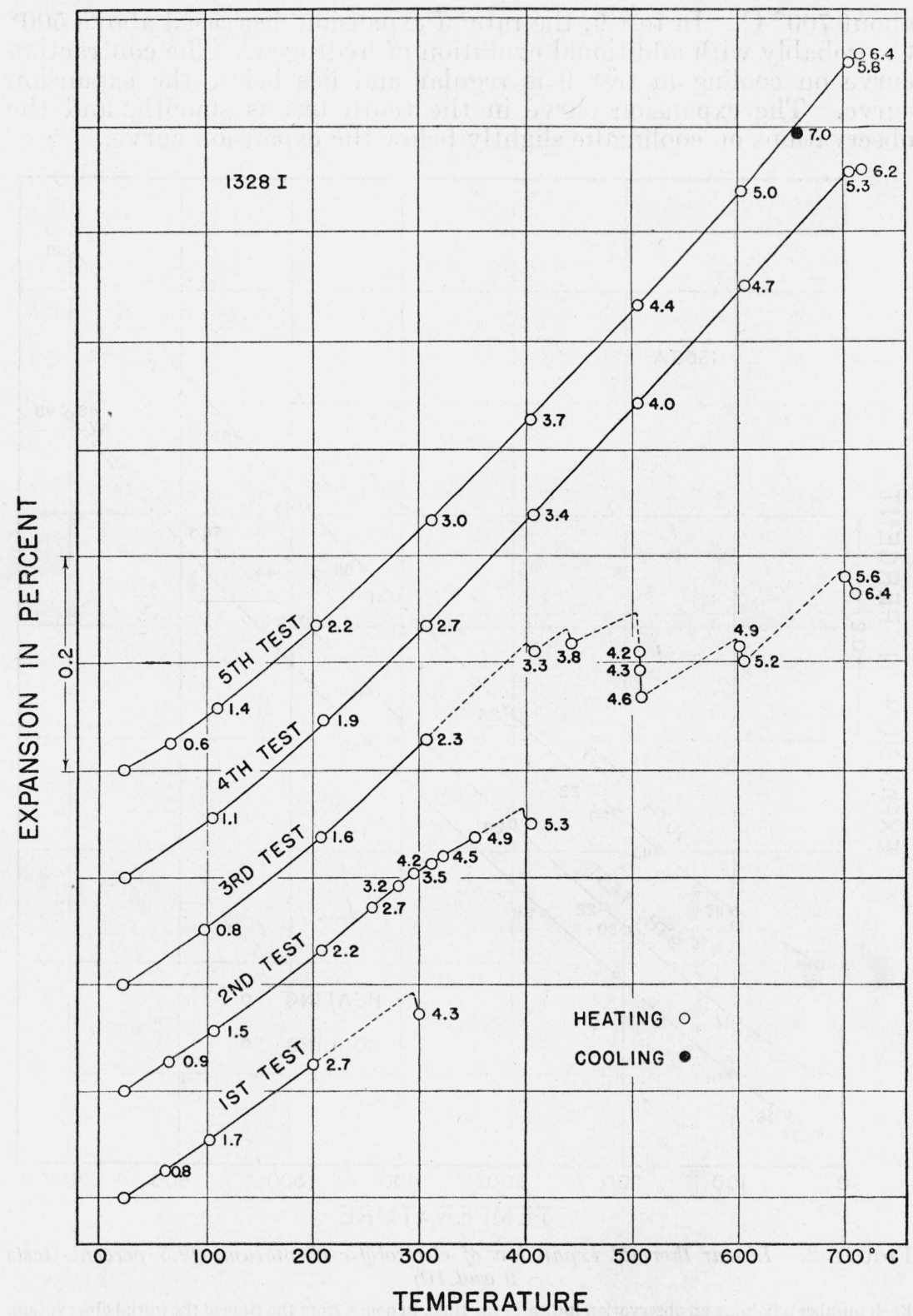

FIGURE 3.-Linear thermal expansion of electrolytic chromium, 98.7 percent Each number adjoining an observation indicates the time, in hours, from the time of the initial observation

to $700^{\circ} \mathrm{C}$ in the third test, and contracted at various temperatures between $400^{\circ}$ and $700^{\circ} \mathrm{C}$. The expansion curves obtained in the fourth and fifth tests are smooth, except for a slight irregularity above $700^{\circ} \mathrm{C}$. The observed contractions and irregularities probably were accompanied by evolution of hydrogen on heating the sample. 
From the results on samples $1359 \mathrm{~A}$ and $1328 \mathrm{I}$, it is apparent that the linear thermal expansion of electrolytic chromium before it is stabilized by repeated heating may be affected by the temperature, hydrogen content or liberation, time and rate of heating, previous heat treatment, etc. After electroly tic chromium has been stabilized, the linear thermal expansion is a function only of the temperature.

Table 2 gives average coefficients of expansion which were computed for various temperature ranges from the expansion and contraction curves. The last column of the table shows the difference in length before and after each expansion test indicated.

From the coefficients of expansion obtained in the tests in which the expansion curves were smooth and free from irregularities (sample $1359 \mathrm{~A}$ on tests 2 to 10 , inclusive, and sample 13281 on tests 4 and 5), the following empirical equation was derived by the method of least squares:

$$
a_{t}=\left(5.88+0.01548 t-0.00001163 t^{2}\right) 10^{-6},
$$

where $a_{t}$ represents the instantaneous coefficient of expansion or the rate of expansion at any temperature, $t$, between $-75^{\circ}$ and $+650^{\circ} \mathrm{C}$. The probable error of $a_{t}$ is $\pm 0.24 \times 10^{-6}$.

The curve representing the coefficients of expansion of the two samples of electrolytic chromium (99.3 and 98.7 percent) at various

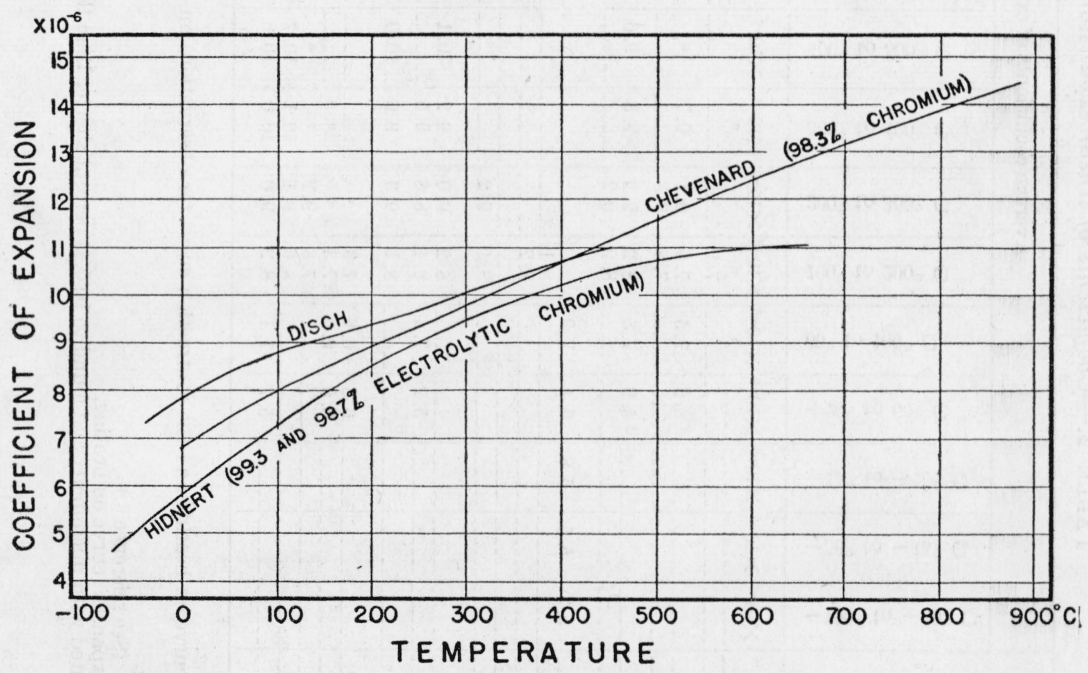

FIGURE 4.-Comparison of instantaneous coefficients of expansion of chromium obtained in the present investigation and in previous investigations by Disch [4] and Chevenard [5].

temperatures between $-75^{\circ}$ and $+650^{\circ} \mathrm{C}$, which was computed from eq 1 , is shown in figure 4 . This figure includes a curve derived from the data by Disch [4] on a sample of chromium of unknown purity and a curve from Chevenard [5] on a sample of chromium containing 98.3 percent of chromium. ${ }^{3}$ Each of the curves is concave toward the temperature axis. At the lower temperatures, the

Impurities principally aluminum and iron, but amounts were not indicated by Chevenard. 
TABLE 2.-Coefficients of linear expansion of electrolytic chromium

\begin{tabular}{|c|c|c|c|c|c|c|c|c|c|c|c|c|c|c|c|c|c|c|c|c|c|c|}
\hline \multirow[b]{2}{*}{ 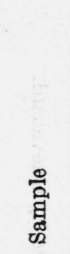 } & \multirow[b]{2}{*}{ 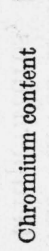 } & \multirow[b]{2}{*}{ Test method } & \multirow[b]{2}{*}{ Testa } & \multicolumn{18}{|c|}{ A verage coefficients of expansion per degree centigrade } & 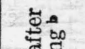 \\
\hline & & & & $\begin{array}{l}0 \\
0 \\
0 \\
1 \\
1 \\
0 \\
0 \\
0 \\
1 \\
1\end{array}$ & $\begin{array}{l}0 \\
0 \\
i 0 \\
1 \\
8 \\
0 \\
0 \\
0 \\
1\end{array}$ & $\begin{array}{l}0 \\
0 \\
0 \\
+ \\
+ \\
8 \\
0 \\
i \\
1\end{array}$ & $\begin{array}{l}0 \\
: \\
\vdots \\
\vdots \\
\vdots \\
\vdots \\
+\end{array}$ & $\begin{array}{l}0 \\
0 \\
8 \\
8 \\
8 \\
8 \\
0 \\
0\end{array}$ & 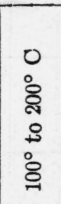 & $\begin{array}{l}0 \\
0 \\
8 \\
8 \\
0 \\
8 \\
: \\
:\end{array}$ & $\begin{array}{l}0 \\
0 \\
8 \\
8 \\
8 \\
8 \\
: \\
:\end{array}$ & $\begin{array}{l}0 \\
0 \\
0 \\
0 \\
8 \\
8 \\
0 \\
8\end{array}$ & 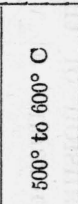 & $\begin{array}{l}0 \\
: \\
8 \\
8 \\
8 \\
\vdots \\
\vdots \\
0\end{array}$ & 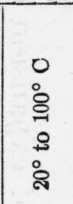 & 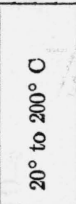 & 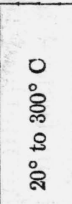 & $\begin{array}{l}0 \\
: \\
\text { \&े } \\
\circ \\
\circ \\
:\end{array}$ & 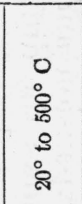 & $\begin{array}{l}0 \\
\vdots \\
8 \\
0 \\
\$ \\
\vdots \\
\vdots\end{array}$ & 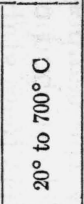 & 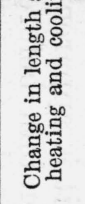 \\
\hline & $\begin{array}{l}\text { Per- } \\
\text { cent }\end{array}$ & & (1⿴囗十⺝- & $\times 10^{-}$ & $\times 10^{-6}$ & $\times 10^{-6}$ & $\times 10^{-6}$ & $\times e^{-6}$ & $\times 10^{-}$ & $\times 10^{-6}$ & $\times 10^{-6}$ & $\times 10^{-6}$ & $\times 10^{-6}$ & $\times 10^{-0}$ & $\times 10^{-6}$ & $\begin{array}{c}\times 10^{-6} \\
0^{\circ}\end{array}$ & $\times 10^{-6}$ & $\times 10^{-0}$ & $\begin{array}{c}\times 10^{-6} \\
0\end{array}$ & $\times 10^{-6}$ & $\times 10^{-6}$ & \\
\hline & & (Precision compara- & $2 \mathrm{H}$ & - & - & $-\cdots$ & d 6.2 & 7.5 & 7.9 & 9.1 & 9.7 & $\circ$ &.---- & -..-. & d 6.8 & d 7.5 & d 8.1 & d 8.5 & $i_{0}$ & & & \\
\hline & & & $3 \mathrm{H}-$ & ..... & . & $-\cdots--$ & d 5.9 & 7.5 & 8. 2 & 9. 2 & 9.8 & 9.6 & $=$ & ....- & d 6.7 & d 7.5 & d 8.1 & d 8.6 & d 8.8 & & & -.008 \\
\hline & & & $(4 \mathrm{H} \cdot$ & 5.3 & 5.5 & 5.8 & 6.4 & 7.2 & & & & & & & 6.8 & & & & & & & \\
\hline $1359 \mathrm{~A}$ & 99.3 & Precision compara- & $6 \mathrm{H}---$ & $\ldots$ & $\ldots$ &.- & 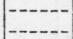 & & 8.2 & $-\ldots-\cdots-$ & 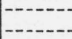 & & 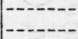 & -.-- & $\begin{array}{l}6.6 \\
6.6\end{array}$ & $\begin{array}{l}7.5 \\
7.5\end{array}$ & $\ldots$ & & $-\cdots \cdot(-\cdots)$ & -.... & $\cdots$ & \\
\hline & & & $8 \mathrm{He}-\mathrm{H}_{-}$ & & & & & & 8.1 & 9.2 & $\cdots$ & $\ldots$ & $-\cdots+$ & $\cdots$ & 6.7 & 7.5 & 8.1 & & $\cdots+\cdots$ & $-\cdots+$ & $\cdots$ & 7.002 \\
\hline & & & $\int_{9 \mathrm{C}}^{9 \mathrm{H}}$ & & & & 52 & 74 & $\begin{array}{l}8.2 \\
8.4\end{array}$ & $\begin{array}{l}9.0 \\
8.8\end{array}$ & $\begin{array}{l}9.2 \\
9.5\end{array}$ & 10.1 & 。 & 。 & $\begin{array}{l}6.8 \\
6.3\end{array}$ & $\begin{array}{l}7.6 \\
7.4\end{array}$ & $\begin{array}{l}8.1 \\
7.9\end{array}$ & $\begin{array}{l}8.4 \\
8.3\end{array}$ & 8.7 & 。 & 。 & -.048 \\
\hline & & & loHe. & & 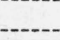 & 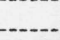 & & & 8.1 & 9.3 & 9.9 & 10.0 & 10.9 & 11.0 & 6. 2 & 7.2 & 8.0 & 8.5 & 8.8 & 9.1 & 9.4 & -.004 \\
\hline $1328 \mathrm{I}$ & 98.7 & Interfer & $\int_{2 \mathrm{H}}^{1 \mathrm{H}}$ & & & - & $\begin{array}{l}6.6 \\
6.6\end{array}$ & $\begin{array}{l}6.9 \\
6.9\end{array}$ & $\begin{array}{l}7.3 \\
7.3\end{array}$ & $:$ & $\circ$ & & & & $\begin{array}{l}6.7 \\
6.8\end{array}$ & $\begin{array}{l}7.1 \\
7.0\end{array}$ & $\therefore 0$ & $\therefore$ & & & & \\
\hline & & & & & & & & & 6 & $\begin{array}{l}9.2 \\
9.1\end{array}$ & 10.1 & 10 & 10 & & & $\begin{array}{l}7.3 \\
7.7\end{array}$ & 2 & 8.7 & 9. & $\begin{array}{l}\circ \\
9.4\end{array}$ & 9.6 & \\
\hline & & & & & & & 5.7 & 7.1 & 8. 2 & 9.0 & 10.0 & 10.6 & & 11.9 & 6.4 & 7.4 & & & 8.9 & 9.3 & 9.7 & \\
\hline
\end{tabular}

a indicates heating, and C, cooling.

b Determined from the expansion curve on heating and the contraction curve (or observation) on cooling. The plus sign indicates an increase in length and the minus sign a decrease in length.

- Evolution of hydrogen on heating.

d Published previously by author. (See reference 6.)

test, sample was measured with micrometer and found to be 0.45 percent shorter than the initial length before first test. 
coefficient of expansion increases rapidly with increasing temperature, but at higher temperatures the coefficient of expansion increases slowly. The coefficients of expansion obtained in the present investigation are less than those obtained by Disch [4] and Chevenard [5].

The following equation was obtained by integrating eq 1 :

$$
L_{\imath}=L_{0}\left[1+\left(5.88 t+0.00774 t^{2}-0.00000388 t^{3}\right) 10^{-6}\right] .
$$

In this equation, $L_{t}$ represents the length at any temperature, $t$, between $-100^{\circ}$ and $+700^{\circ} \mathrm{C}$ and $L_{0}$, the length at $0^{\circ} \mathrm{C}$.

Table 3 gives a comparison of average coefficients of expansion of chromium computed from eq 2 and from data by Disch [4].

TaBle 3.-Comparison of coefficients of expansion of chromium

\begin{tabular}{|c|c|c|}
\hline \multirow{2}{*}{$\underset{\text { range }}{\text { Temperature }}$} & \multicolumn{2}{|c|}{$\begin{array}{l}\text { Average coefficients of } \\
\text { expansion per degree } \\
\text { centigrade }\end{array}$} \\
\hline & $\begin{array}{l}\text { Present in- } \\
\text { vestigationa }\end{array}$ & $\begin{array}{l}\text { Previous in- } \\
\text { vestigation }\end{array}$ \\
\hline $\begin{array}{c}{ }^{\circ} \mathrm{C} \\
-100 \text { to } 0 \\
0 \text { to } 100 \\
0 \text { to } 200 \\
0 \text { to } 300 \\
0 \text { to } 400 \\
0 \text { to } 500 \\
0 \text { to } 600 \\
0 \text { to } 700\end{array}$ & $\begin{array}{c}\times 10^{-6} \\
5.1 \\
6.6 \\
7.3 \\
7.9 \\
8.4 \\
8.8 \\
9.1 \\
9.4\end{array}$ & $\begin{array}{c}\times 10^{-6} \\
07.3 \\
8.4 \\
8.8 \\
9.1 \\
9.4 \\
9.7 \\
\\
\end{array}$ \\
\hline
\end{tabular}

a Computed from eq 1.

- Computed by author from data by Disch [4].

- From $-78^{\circ}$ to $0^{\circ} \mathrm{C}$.

\section{DISCUSSION}

Disch [4] stated that the sample of chromium which he investigated indicated a behavior similar to that of fused quartz. He found that this sample contracted on cooling until the temperature reached about $-183^{\circ} \mathrm{C}$, but it expanded on further cooling. He was unable to obtain accurate values, for the surfaces of the chromium sample deformed at low temperatures. The contraction between $+20^{\circ}$ and $-183^{\circ} \mathrm{C}$ was $1.25 \mathrm{~mm} / \mathrm{m}$, and that between $+20^{\circ}$ and $-190^{\circ} \mathrm{C}$ was $1.0 \mathrm{~mm} / \mathrm{m}$.

Chevenard [5] found that the linear thermal expansion of a sample of chromium (98.3 percent) was reversible between $0^{\circ}$ and $100^{\circ} \mathrm{C}$. His sample of chromium did not appear to have any thermal singularity between $0^{\circ}$ and $900^{\circ} \mathrm{C}$ (See fig. 4).

The results by Hidnert [6] in 1931 and the present investigation indicate that irregularities in the linear thermal expansion of electrolytic chromium may be related to evolution of hydrogen. Grube and Knabe [9] also found irregularities in the temperature-resistance curves of electrolytic chromium, which they stated can be traced to the hydrogen content.

It appears to the author that the fine cracks which may be seen in some chromium plates subjected to temperature changes may be as- 
cribed to evolution of hydrogen, which causes permanent shrinkage of the plates.

That the quantity of hydrogen liberated may be appreciable is also evident from the results reported by Adcock [10]. As a sample of carefully dried electrodeposited chromium lost 0.1 percent of its weight when heated to $900^{\circ} \mathrm{C}$ under vacuum conditions, he presumed that the metal contains about this percentage of hydrogen, which is in agreement with the value reported in 1931 [6] for chromium produced at the National Bureau of Standards. He stated that it seems definitely established that electrodeposited chromium also contains oxygen in some form.

From the results in table 1 it is evident that the density of the sample of electrolytic chromium (99.3 percent) increased 2.4 percent after 3 cycles of heating to $500^{\circ} \mathrm{C}$ and cooling to room temperature. The initial mass and volume of the sample were $37.954 \mathrm{~g}$ and $5.474 \mathrm{ml}$, respectively. After the three cycles of heating and cooling, the mass and volume were $37.978 \mathrm{~g}$ and $5.347 \mathrm{ml}$. In spite of evolution of hydrogen from the sample, its mass increased $0.024 \mathrm{~g}$, or 0.06 percent. It appears that the sample oxidized during heating in air, and that more than 0.06 percent of oxygen, by weight, was absorbed by the sample. The volume of the sample decreased $0.127 \mathrm{ml}$, or 2.3 percent.

The first heatings of electrolytic chromium, which reduce or eliminate the content of hydrogen, affect other properties, as well as the linear thermal expansion. The electrical resistivity ${ }^{5}$ of a sample of electrolytic chromium prepared at this Bureau decreased nearly 50 percent after heating to $500^{\circ} \mathrm{C}$ and cooling to room temperature. Additional heating to a higher temperature and cooling to room temperature caused a further decrease in the electrical resistivity. Adcock [10] found that the Brinell hardness number of electrolytic chromium decreased about 60 percent during heating to $900^{\circ} \mathrm{C}$ in vacuo. $\mathrm{He}$ found that the Brinell hardness number decreased still more if the chromium was treated with hydrogen at $1,500^{\circ}$ to $1,600^{\circ} \mathrm{C}$ to remove oxide.

\section{SUMMARY AND CONCLUSIONS}

The linear thermal expansion of two samples of electrolytic chromium (99.3 and 98.7 percent) was investigated at various temperatures between $-105^{\circ}$ and $+715^{\circ} \mathrm{C}$ with a precision comparator method and with an interference method. A total of 15 tests was made.

The samples of electrolytic chromium contracted during the first heating when hydrogen presumably was evolved. It was possible to obtain smooth expansion curves after repeated heating.

After the first heating to $500^{\circ} \mathrm{C}$ and cooling to room temperature, the sample of electrolytic chromium containing 99.3 percent of chromium was 1.1 percent shorter than the initial length before heating. A smaller change was noted for the other sample of electrolytic chromium.

The linear thermal expansion of electrolytic chromium before it is stabilized, by repeated heating, is a function of the temperature, hydrogen content or liberation, time and rate of heating, previous treatment, etc. After repeated heatings of electrolytic chromium, the linear thermal expansion is a function only of the temperature.

\footnotetext{
${ }^{3}$ Information about electrical resistivity was furnished by I. L. Cooter, of this Bureau.
} 
From the coefficients of expansion obtained in tests in which the expansion curves were smooth and apparently not affected by hydrogen, the following equations were derived:

and

$$
a_{t}=\left(5.88+0.01548 t-0.00001163 t^{2}\right) 10^{-6}
$$

$$
L_{t}=L_{0}\left[1+\left(5.88 t+0.00774 t^{2} 0.00000388 t^{3}\right) 10^{-6}\right],
$$

where $a_{t}$ represents the instantaneous coefficient of expansion or rate of expansion at any temperature, $t$, between $-75^{\circ}$ and $+650^{\circ} \mathrm{C}$; $L_{0}$ represents the length at $0^{\circ} \mathrm{C}$; and $L_{t}$ the length at any temperature, $t$, between $-100^{\circ}$ and $+700^{\circ} \mathrm{C}$. Figure 4 and table 3 give coefficients of expansion computed from eq 1 and 2, and show comparisons with data from other observers.

The volume of the sample of electrolytic chromium containing 99.3 percent of chromium decreased 2.3 percent after three cycles of heating to $500^{\circ} \mathrm{C}$ and cooling to room temperature. The density increased 2.4 percent, for the mass of the sample increased only 0.06 percent.

\section{REFERENCES}

[1] W. Blum, W. P. Barrows, and A. Brenner, The porosity of electroplated chromium coatings, BS J. Research $\boldsymbol{y}, 697$ (1931) RP368.

[2] W. Blum, P. W. C. Strausser, and A. Brenner, Protective value of nickel and chromium plating on steel, J. Research NBS 13, 331 (1934) RP712.

[3] W. Blum and P. W. C. Strausser, Outdoor exposure tests of electroplated nickel and chromium coatings on steel and nonferrous metals, J. Research NBS 24, 443 (1940) RP1293.

[4] J. Disch, Über die Wärmeausdehnung einiger Stoffe, Z. Physik 5, 173 (1921); Wiss. Abh. Physik.-tech. Reichanstalt 5, 263 (1921).

[5] P. Chevenard, Dilatabilité du chrome et des alliages nickel-chrome dans un intervalle étendu de températures, Comptes rend. 1\%4, 109 (1922).

[6] P. Hidnert, Thermal expansion of electrolytic chromium, Phys. Rev. 39, 186 (1932).

[7[ W. Souder and P. Hidnert, Measurements on the thermal expansion of fused silica, Sci. Pap. BS 21, 1 (1926) S524.

[8] G. E. Merritt, The interference method of measuring thermal expansion, BS J. Research 10, 59 (1933) RP515.

[9] G. Grube and R. Knabe, Elektrische Leitfähigkeit und Zustandsdiagram bei binären Legierungen, Z. Elektrochem. 42, 793 (1936).

[10] F. Adcock, Alloys of iron research. Part 4, The preparation of pure chromium, Nat. Phys. Lab. Collected Researches 25, 49 (1935).

Washington, October 18, 1940. 